\title{
Universal healthcare - through the eyes of a medical student
}

\author{
V F Stock, 3rd-year medical student \\ Faculty of Health Sciences, University of Witwatersrand, Johannesburg, South Africa
}

Corresponding author: VF Stock (victoriastock@gmail.com)

\begin{abstract}
Had I been tasked with writing an article on universal healthcare it is unlikely that it would have addressed any of the issues that Victoria Stock has in her article. This is not a criticism of the author but an endorsement of the idea of not only encouraging students to write on subjects of an ethical nature but also to disseminate their views further. Issues addressed by her range from poor student attendance through to taxation and thoughts on distributive justice. Clearly she has thought about the subject and is willing to reflect not only on major issues but also on her experiences close to hand.

Ethics appears to be alive and well at the University of Witswatersrand and students are engaging. An undergraduate student manages to bring the weighty subject of universal healthcare directly to the level of students and their clinical involvement. This reflects exactly what the Medical Protection's motivation was to be involved in the exercise - to make ethics real, relevant and engaging; to encourage the future of the profession to participate.

Read the article for what it is, not what you think it may lack. This is an undergraduate medical student with virtually no formal training in logic or bioethics and she opens up an interesting vista. Read it critically and think for yourself. My angle, given my background, may have been on money and resources wasted or money wasted to litigation. What would yours have been? Graham Howarth
\end{abstract}

\begin{abstract}
Regardless of which bioethical theory one consults - be it, for example, utilitarianism, which states that one must do the most good for the greatest number of people, 'An action is morally right if the consequences of that action are on balance more positive than negative for the greatest number'; ;i] or perhaps deontology, which is duty theory'there are certain actions which we have a duty to perform or to refrain from performing $^{\prime[1]}$ - one will likely come to the conclusion that universal healthcare is an ideal which, if at all possible, should be achieved by mankind. It is a question of human rights, and respect for one's fellow man, or perhaps, more fundamentally treating those around us with the care we would expect for ourselves, or family members. In this article, I shall attempt to unravel universal healthcare as an ideal. To bring it down to fundamentals and perhaps make suggestions towards how such an ideal may be realised. I will look at relevant healthcare systems, which have been implemented overseas, and compare them with what government hopes to implement in South Africa (SA) - a National Health Insurance. Most importantly, I will analyse universal healthcare in the context of SA, and establish whether this ideal is attainable. Universal healthcare is the gem of healthcare in the 21st century. It is what all healthcare professionals would love to achieve within their lifetimes, but to achieve a goal as immense as this, one needs to build from the foundations upwards. As such, I shall discuss and suggest ways in which healthcare students can contribute to this ultimate ideal.
\end{abstract}

S Afr J BL 2015:8(2):7-10. DOI:10.7196/SAJBL.438

Could the implementation of National Health Insurance $(\mathrm{NHI})$, be the answer to universal healthcare in South Africa (SA)? In theory, yes - an NHI policy in SA would formalise access to healthcare for all walks of life, regardless of income, race, gender or religion - as is due to one according to the Bill of Rights, chapter 2 of the South African Constitution.

'Health care, food, water and social security Section 27:

1. Everyone has the right to have access to:

- Health care services, including reproductive health care;

- Sufficient food and water; and

- Social security, including, if they are unable to support themselves and their dependants, appropriate social assistance

2. The state must take reasonable legislative and other measures, within its available resources, to achieve the progressive realisation of each of these rights.

3. No one may be refused emergency medical treatment. ${ }^{[2]}$

However, a key point in the Bill of Rights is section 27, point 2: 'The state must take reasonable legislative and other measures, within its available resources, to achieve the progressive realisation of each of these rights. ${ }^{[2]}$ The specification of 'within its available resources', gives the state leeway in realising these basic human, and constitutional rights on account of insufficient resources. For the financial year 2014/15, the South African Treasury budgeted ZAR145.7 billion for Health. ${ }^{[3]}$ That is an increase from the 2013/14 financial year of ZAR11.4 billion. ${ }^{[3]}$ This increase was aimed at making the human papilloma virus (HPV) vaccine available, to decrease the incidence of cervical cancer; ${ }^{[4]}$ launching the Office of Health Standards Compliance - an independent body responsible for making sure that healthcare facilities are operating optimally;i] further HIV/AIDS treatment ${ }^{[4]}$ and lastly, on clinic refurbishment. ${ }^{[4]}$

These expenditures are all in line with the achievement of universal healthcare. But it is the NHI that truly holds the key. The NHI, which the SA government plans to implement, so far aims to provide primary healthcare to anyone who is not a member or beneficiary of a private medical aid scheme. ${ }^{[5]}$ This is to ensure that members of the general populace, who are not earning enough money to afford private health insurance, will have free access to community centres and clinics through the NHI. However, the National Health Act, No. 61 of 2003 has been around for over 10 years, and there are still members 
of the general population suffering without proper access to medical treatment - be it in rural areas, where people have to walk for hours to reach their nearest clinic, or people in more urban areas, who perhaps deal with poor quality of treatment, and a lack of resources because of so many people being in the catchment area of each clinic. The National Health Act, as it currently stands, makes it sound as if everyone who cannot afford proper healthcare can go to a government facility to receive treatment. However, these facilities remain shortstaffed and under-resourced.

With the implementation of a proper $\mathrm{NHI}$ in this country, would the situation improve? A better NHI system would indeed ensure that members of the population have free access to healthcare. But would this improve the quality of care given at community centres and clinics? Would the implementation of a better NHI policy mean that more clinics are built in rural areas? And would availability of resources, including human resources improve?

I believe the answer is no. No Acts of Parliament will improve quality of care, until healthcare practitioners find it in themselves to help patients more compassionately, and until more money is allocated to beds, food and general upkeep of these healthcare facilities. Achieving good health is largely dependent on the availability of social determinants. This is not taken into consideration in the Green Paper on NHI. If transport options are not available for people in rural areas, how will they reach health facilities? And lastly, the implementation of an improved NHI would not necessarily mean that more doctors and nurses would work in the public sector, rather than in the private sector; and there is again, no guarantee that there would be enough resources such as bandages, bedding, suturing packs, etc. for the general treatment of patients.

The major blockade to quality universal healthcare is not the lack of a law proclaiming that all patients have the right to quality healthcare, but rather a lack of financial backing and availability of resources which the SA government continues to fail to provide to better, and to promote quality in, public healthcare.

\section{Achieving universal access to healthcare}

Is universal access to healthcare achievable?
Many countries, such as the UK, Denmark and Sweden have NHI systems, which prioritise quality universal care within the bounds of their countries. But is such an achievement attainable in a country like SA?

The comparison is difficult because the UK, Denmark and Sweden are all first-world, or developed countries, while SA, while it has areas which qualify as developed, is on the whole a developing country. As such, the three developed countries have much larger access to funds and because of this they can afford to allocate larger proportions of their national budget to health. When analysing the statistics in Table 1 it is important to note that not only does SA have the smallest budget allocation for health of these four countries, but SA is also not only a larger country geographically, but the population far exceeds that of Denmark and Sweden.

One of the most obvious problems with the SA healthcare system, with reference to the above statistics, is the lack of doctors. SA has a ratio of less than one doctor per thousand people. This is a huge obstacle, which needs to be overcome if $S A$ is to rise in the global comparison of healthcare systems. One way to overcome such an obstacle would be to improve the standard of working conditions for healthcare practitioners in SA, as there are many graduates who immigrate to countries such as Australia and the UK. Another idea would be to increase the salary of government-employed healthcare practitioners, to incentivise working in the public sector, rather than seeking higherpaying private sector positions.

In addition to a severe lack of healthcare professionals, it is clear that the ZAR145.7 billion that SA spends on health is insufficient to cover the requirements of a universal healthcare system. In order to gain sufficient revenue to support an $\mathrm{NHI}$ capable of being truly universal there are a few areas in which SA could improve. For example, either tax would need to be increased, or budget from other sectors would have to be re-allocated to health. In the case of an increase in tax, one would have to clarify a number of points - what type of tax would this new tax be? Would it be aimed at specific income brackets? And how would one make sure that these additional funds would find their way to the health sector rather than to other sectors within the government's budget?

One idea is to increase so called 'sin-tax', that is a tax on luxury items such as alcohol or cigarettes. The reason I suggest such a tax is that these luxury items, especially alcohol and cigarettes, are huge risk factors with regards to personal health. Smoking is a risk factor for most diseases, including, but not limited to cancer, stomach and duodenal ulcers, diabetes mellitus, as well as having a hugely negative impact on the rate of wound healing. Alcohol, on the other hand, is a major cause of liver cirrhosis, as well as a major cause of motor-vehicle accidents which may have otherwise been avoided. Therefore, discouraging the use of these substances by increasing tax may cause a decrease in the hospitalisation of patients with illnesses related to these substances, and decrease the burden that weighs down upon our public health system.

SA could also increase tax revenue by increasing corporate income tax, fuel levies and customs and excise duties. The aim of this would be to institute a small increase in all three of these brackets, but not so much as to discourage international investment. This would contribute greatly to the revenue, and these funds could then be allocated to health.

In the case of increasing the health budget through re-allocation of funds from other sectors, one would have to establish a priority scale among the sectors to which the government allocates funds. For instance, SA does not have a great need for a large

Table 1. Healthcare allocation comparison

\begin{tabular}{lllll}
\hline Country & $\begin{array}{l}\text { \% of GDP spent } \\
\text { on health }\end{array}$ & $\begin{array}{l}\text { Approximate } \\
\text { amount in } \\
\text { ZAR }\end{array}$ & $\begin{array}{l}\text { Number of } \\
\text { physicians } \\
\text { per } \mathbf{0 0 0} \\
\text { population }\end{array}$ & $\begin{array}{l}\text { Number } \\
\text { of beds } \\
\text { per } \mathbf{1 0 0 0} \\
\text { population }\end{array}$ \\
\hline UK $^{[7,9]}$ & 9.3 & 2.505 trillion & 2.77 & 3 \\
Denmark $^{[8,9]}$ & 11.2 & 196 billion & 3.42 & 3.5 \\
Sweden $^{[10,11]}$ & 9.4 & 321 billion & 3.8 & 2.8 \\
South Africa $^{[3,12]}$ & 8.5 & 145.7 billion & 0.76 & 2.8
\end{tabular}


defence force budget, but there is a huge need for a health and education budget. In the 2014/15 financial year, SA allocated ZAR47.9 billion to the defence force ${ }^{[3]}$ this could be decreased to perhaps ZAR40 billion, and the difference could be re-allocated to health. Another option would be to decrease subsidies in departments such as agriculture, forestry and fisheries and general economic and commercial affairs. These gained funds could subsequently be used to build more clinics and hospitals, or to create a transport service for rural patients to gain access to healthcare facilities which they would otherwise have to walk to. Another area where the government could streamline funds within the healthcare system would be to institute independent auditors of the funds, which flow through government structures - the aim of which would be to decrease and hopefully eliminate corruption and fund misappropriation and ensure that the funds, which have been allocated to healthcare, are spent appropriately.

Further, the government could opt to allow private investors to buy shares in various hospitals. This would solve the problem as it stands, of not having enough financial resources to keep hospitals running smoothly, with sufficient medical equipment and disposables available to administer quality care to patients. This would also 'freeup' the budget allocated to health in order to help other struggling healthcare facilities that are still $100 \%$ government owned. The downside of this arrangement would be that the government would no longer have $100 \%$ control of public hospitals, and this means there is a potential for price changes due to competition between hospitals, which are semi-privately owned. Although there would almost certainly be an improvement in quality, there would also almost definitely be an increase in prices as private investors would expect returns on their investments. These changes in pricing may prevent standardisation, but they would also likely help move this country closer to achieving universal healthcare. Ideally, a universal healthcare system would be government controlled so as to standardise issues such as quality and costing, but unfortunately, in order to achieve universal quality care, we may need to open up the opportunity of investment to private individuals.

A further implementation, which could improve general healthcare in this country, would be to make it possible for government patients to be treated at private facilities at the expense of the government. This would decrease the necessity of building new hospitals and clinics in the short term, while still making quality healthcare available to public sector patients. This would require legislation, and also hugely increased communication and co-operation between public and private healthcare providers such as large companies including Life and Netcare, large private insurance companies, such as Discovery, and the government health portfolio.

These changes are obviously not going to happen overnight, but I believe that taking steps in the directions that I have suggested would greatly increase SA's ability to look after their own, and to properly supply quality care to citizens, regardless of socioeconomic status.

\section{The role of students}

There are many ways in which we, as students, can start making a difference here at university. Firstly, I think that societies such as the Wits Students' Bioethics Society are essential for creating awareness and promoting free thought among students of all ages. The Wits Students' Bioethics Symposium, which took place in March 2015, is a classic example of students educating other students in the field of bioethics and opening the doors to free communication about the topics that are so pertinent to our field of work in the Faculty of Health Sciences. It is essential that students attend such events and make any problems, that they have been made aware of, known to other students at these events.

Secondly, I think that students ought to feel ethically bound to report any malpractice or shortcomings which they may find or experience during their time in hospitals and clinics during their clinical rotations. Students should also give their all to learn and help while on these rotations. So often, we find students leaving early, or arriving late, and then not assisting in the ward to which they were allocated. What makes students believe that they are above helping in certain wards? What makes students feel that it is acceptable to arrive late or leave early from these sessions? I feel that the onus should be placed on students to report their fellows who are slacking. These clinical rotations are not just an incredibly important part of one's education as a healthcare practitioner, but also an amazing opportunity for students to assist the heavily overworked nurses and doctors in each ward. With such an immense shortfall in the numbers of healthcare practitioners in this country, students should be responsible for any small duties concerning patient care and assisting the qualified doctors and nurses in their daily duties, so as to allow qualified individuals to take care of tasks which require a higher level of skills and knowledge. The fact that students neglect full participation is a gross failing on their part, as not only are they not learning the clinical and practical skills necessary for them to become competent healthcare professionals one day, but they are also shirking the duty which they have to the patients and healthcare professionals in the ward to which they have been allocated. If students were to do their duties in their wards, this would greatly alleviate the workload of other healthcare professionals, which would in turn assist in addressing the issue of understaffing that is everpresent in government facilities.

Lastly, I think that students should be encouraged to educate themselves on issues of health law and government policy, which influences the sphere of healthcare. It is vastly important in a field which not only desires, but requires redesign, that the students of today should prepare themselves for a long-term fight for improved healthcare in this country.

\section{Conclusion}

We, the current students in the country are soon going to be in a position, as qualified practitioners, to become involved, through relevant councils, in the changing of policies of law and healthcare administration. We should take it upon ourselves to be the driving force behind initiatives such as an $\mathrm{NHI}$, and work to see these structures built into our everyday lives. And although, as it stands, SA cannot afford to implement the form of $\mathrm{NHI}$ that we would so love to see, as individuals, we can try to make a difference at the grassroots level. Whether a student chooses to volunteer at a clinic on free days, or merely take the time to truly care for each patient we encounter, small deeds such as these will eventually cause a domino effect of improved quality of care in our country. As residents, as citizens and as future healthcare professionals, it falls to us to try and empower our people through quality care and treatment. It is hoped, that with improved economic stability and an increased national revenue, that 
one day the infrastructure will be put into place to make this dream of universal care a reality.

\section{References}

1. Behrens K. Introduction to Bioethics and Ethical Theory. Wits Medical School, University of the Witwatersrand, Johannesburg. 11 February 2015.

2. Republic of South Africa. South African Constitution, Bill of Rights, Chapter 2, Section 27. Health care, food, water and social security. Government Gazette, 1996. http://www.westerncape.gov.za/legislation/bill-rights-chapter-2-constitutionrepublic-south-africa\#7 (accessed 22 February 2015).

3. National Treasury, South Africa. Budget 2014 Highlights, Pretoria: National Treasury, 2014.

4. National Treasury, South Africa and South African Revenue Service. People's guide to the Budget. Pretoria: National Treasury, 2014.

5. Republic of South Africa. National Health Amendment Act 61 of 2003. Chapter 1 point 4.3.b. Page 15. Government Notice 869. Pretoria: Government Gazette 26595, 23 July 2004.

6. House of Commons, HM Treasury, United Kingdom. Budget 2014. London: House of Commons, 19 March 2014. https://www.gov.uk/government/ uploads/system/uploads/attachment_data/file/293759/37630_Budget_2014_ Web_Accessible.pdf (accessed 22 February 2015).
7. Central Intelligence Agency. Fact-book: United Kingdom. Washington: Centra Intelligence Agency, 2014. https://www.cia.gov/library/publications/the-worldfactbook/geos/uk.html (accessed 22 February 2015).

8. Organisation for Economic Cooperation and Development (OECD). Data Denmark France: OECD, 2015. http://data.oecd.org/denmark.htm\#profile-health (accessed 21 February 2015)

9. Central Intelligence Agency Fact-book: Denmark. Washington: Central Intelligence Agency, 2014. https://www.cia.gov/library/publications/the-worldfactbook/geos/da.html (accessed 22 February 2015).

10. Organisation for Economic Cooperation and Development. OECD indicators, health at a glance. France: OECD, 2013. http://data.oecd.org/healthres/healthspending.htm\# (accessed 21 February 2015).

11. Central Intelligence Agency. Fact-book: Sweden. Washington: Central Intelligence Agency, 2014. https://www.cia.gov/library/publications/the-world-factbook/ geos/sw.html (accessed 22 February 2015).

12. Central Intelligence Agency. Fact-book: South Africa. Washington: Central Intelligence Agency, 2014. https://www.cia.gov/library/publications/the-worldfactbook/geos/sf.html (accessed 22 February 2015).

13. Republic of South Africa. Policy paper, National Health Insurance in South Africa. Pretoria: Government Gazette, 2011. http://www.gov.za/sites/www.gov.za/files/ nationalhealthinsurance.pdf (accessed 22 February 2015). 